\title{
SOLUÇÃO CONSENSUAL E A AUDIÊNCIA DO ART. 334 DO NOVO CPC VERSUS MEDIAÇÃO COMO FACULDADE DAS PARTES
}

\author{
Elaine Harzheim Macedo ${ }^{1}$
}

\begin{abstract}
Resumo
O presente estudo parte da afirmação do processo como espaço democrático de direito, com foco nos institutos de conciliação e de mediação contemplados na audiência preliminar do art. 334 do novo CPC e sua indistinta e genérica cogência. Como análise crítica realiza-se uma comparação entre a Lei n. 13.140/15 e o novo CPC, em especial no que diz com a autonomia de vontade e a regra de que ninguém será obrigado a permanecer em procedimento de mediação, acusando uma diametral divergência entre os dois estatutos. Trabalha-se, outrossim, com as ínsitas dificuldades de organização judiciária para bem realizar o propósito legal de estímulo à autocomposição ou composição consensual, partindo-se, destarte, mediante uma metodologia dedutiva, de uma premissa maior e mais genérica para uma menor e mais específica, através de pesquisa bibliográfica, ao efeito de alcançar uma compreensão melhor da mediação e sua aplicação aos processos judiciais, propondo-se a adoção da mediação como faculdade das partes, de modo a permitir a concretização de um processo civil efetivamente democrático, de amplo acesso e de efetividade de seus fins.
\end{abstract}

Palavras-chave: Solução consensual. Cogência da Audiência preliminar. Conciliação judicial. Mediação como faculdade das partes.

\section{INTRODUÇÃO}

O novo Código de Processo Civil, instituído pela Lei n. 13.105, de 16 de março de 2015, cujo início de vigência restou plasmado pelo Superior Tribunal de Justiça para o dia 18 de março de $2016^{2}$, entre as possíveis e necessárias críticas e encômios que o texto provoca e prosseguirá provocando, inovou no trato da resolução do conflito, resgatando de velhas e não tão bem-sucedidas práticas um caminho alternativo constituído pela solução consensual.

Nesse fio, no capítulo preambular das normas fundamentais do processo civil - marco inquestionável e definitivo da constitucionalização do processo - o art. $3^{\circ}$ que cuida, no seu caput, do acesso à justiça, cláusula

\footnotetext{
${ }^{1}$ Doutorado em Direito pela Universidade do Vale do Rio dos Sinos. Professora catedrática adjunta, permanente, da Pontifícia Universidade Católica do Rio Grande do Sul. Professora palestrante da Escola Superior de Magistratura Ajuris. Membro editorial da Revista da Ajuris. E-mail: elaine@fhm.adv.br

2 http://www.stj.jus.br/sites/STJ/default/pt_BR/Comunica\%C3\%A7\%C3\%A3o/Not\%C3\%ADcias/Not\%C3\%ADcias/STJsai-na-frente-e-adequa-regimento-interno-ao-novo-C\%C3\%B3digo-de-Processo-CivilSTJ, acesso em 27.03.2016.
} 
constitucional elevada à garantia dos direitos individuais e coletivos, e que em seus $₫ \$ 2^{\circ}$ e $3^{\circ}$, estabelece:

$\$ 2^{\circ}$. O Estado promoverá, sempre que possível, a solução consensual dos conflitos.

$\$ 3^{\circ}$. A conciliação, a mediação e outros métodos de solução consensual de conflitos deverão ser estimulados por juízes, advogados, defensores públicos, e membros do Ministério Público, inclusive no curso do processo judicial.

Bastam tais dispositivos - qualificados como normas fundamentais do novo processo civil - para se concluir que houve, sim, uma mudança de paradigma. A autocomposição até então vista, pela lei processual e pelos operadores do processo, como uma fase ou momento processual onde seria proposta uma conciliação, sem qualquer comprometimento maior com o sistema de solução de conflitos e suas variáveis, não mais perdura.

Como corolário desse modelo proposto, inúmeros são os artigos do Código voltados a regulamentar a solução consensual, que pode ser vista a partir do todo ou apenas de parte do processo, minimizando sua vocação adversarial que conta com séculos de prática. A proposta de solidificar um processo consensual não é mera utopia, mas, admite-se, é como remar contra a maré, exigindo do intérprete e/ou do operador um repensar o processo! Nesse diapasão, apontam-se algumas das inovações: a criação de centros judiciários de solução de conflitos e a inclusão de conciliadores e mediadores judiciais como órgãos auxiliares da justiça (arts. 165/173); a previsão de câmaras de mediação e conciliação no âmbito extrajudicial junto aos entes públicos (arts. 174/175); a recorrente expressão de "outras formas" de solução consensual, utilizadas tanto no art. $3^{\circ}, \$ 3^{\circ}$, como no art. 175, revitalizando e ampliando, por exemplo, o espectro de atuação consensual no TAC (termo de ajustamento de condutas), regulamentado pela Lei da Ação Civil Pública, art. 5º \$ 6º as transações processuais (arts. 190, 191, 357, \$ 2º etc).

Nesse universo onde as formas de autocomposição dos conflitos ganham relevância, com ou sem participação do Poder Judiciário, a audiência do art. 334 do CPC/2015 contribui para a constituição de um novo paradigma processual a merecer estudo e reflexão, o que abrange também seu procedimento, sempre sob o viés crítico e construtivo, pela significativa estratégia democrática, representada pela participação direta daqueles que serão os destinatários diretos da composição e que se submeterão aos seus efeitos, ou seja, as partes.

Estabelecem-se, nesse momento, dois marcos significativos, que dão sustentação teórica ao trabalho desenvolvido: (i) compreender o processo civil como espaço democrático, a partir da doutrina processual constitucional; (ii) reconhecer como dimensão qualitativa deste processo a otimização das soluções consensuais, conforme doutrina que defende a jurisdição a partir de uma compreensão de um tribunal multiportas, aberto a soluções alternativas dos conflitos.

Como caminho investigativo, utilizar-se-á da metodologia dedutiva, partindo-se de uma premissa maior e mais genérica para alcançar-se um resultado mais específico, valendo-se da investigação bibliográfica, sem descartar o manejo do direito material, ainda que no plano de exemplos, ao efeito de desvelamento do texto normativo. 


\section{FUNDAMENTOS DO PROCESSO CIVIL COMO ESPAÇO DEMOCRÁTICO DE SOLUÇÃO DE CONFLITOS: PARTICIPAÇÃO E DELIBERAÇÃO}

A Constituição de 1988 ao estabelecer o Estado democrático de Direito e a dignidade da pessoa humana como vetores maiores da nação brasileira instituiu uma democracia não só representativa mas também participativa, refletindo-se esse novo dogma, a partir do art. $2^{\circ}$ e parágrafo único do art. $1^{\circ}$ da $\mathrm{CR}$, na jurisdição, resultando que o processo passa a ser compreendido como espaço democrático de composição de conflitos, não mais se sustentando um processo civil unicentrista, de estrutura inquisitiva, concentrando-se na pessoa do juiz irrelevante se de primeiro grau ou de instâncias recursais - todo o poder para a composição dos conflitos, independentemente se tais conflitos são subjetivos individuais, coletivos ou repetitivos, esses últimos tão afeitos à sociedade de consumo, ou ainda se versem sobre questões meramente patrimoniais ou sobre direitos indisponíveis ou, por derradeiro, se tais direitos envolvam interesse dos entes públicos.

Tradicionalmente, na doutrina posterior à Constituição de 1988, sempre se defendeu - e aqui, por todos, colaciona-se a doutrina de Luiz Guilherme Marinoni e Daniel Mitidiero ${ }^{3}$ - o processo justo como direito fundamental a partir da previsão constitucional das garantias processuais constitucionais que constituem ou devem constituir seu núcleo central ou, em outras palavras, seu conteúdo mínimo, vindo o novo Código de Processo Civil ao encontro dessas legítimas expectativas. A essa premissa outra se agrega: sem se pretender explorar o conceito do processo justo, presente o corte de conhecimento imposto ao trabalho, não é possível reconhecer o processo justo sem a sua qualificação como processo democrático. Aliás, a ideia de processo justo não renuncia à ideia de processo democrático, porque fora da democracia não há que falar em justiça.

Definir o que seja processo democrático no campo do processo civil não é tarefa fácil e demanda, por si, trabalho específico. Em apertada síntese, é preciso se ter presente que a cláusula constitucional maior do Estado brasileiro assentada na democracia pressupõe, por óbvio excluídos os debates sobre o exercício democrático no âmbito dos Poderes Executivos e Legislativos, que também o exercício da jurisdição, função precípua do Poder Judiciário, se qualifique como democrático.

Mesmo que resguardadas as devidas modulações - cuja indispensabilidade se reconhece, considerando em determinados conflitos a presença de interesses de maior repercussão como direitos sociais, meio ambiente, tutela da democracia, onde certamente o protagonismo judicial até poderá ser recepcionado com mais valia -, há que se pensar o processo por um olhar divergente, compreendendo-o como um espaço onde efetivamente as partes - que deixam de ser mero "sujeitos" - passam a exercer a condição de agentes, atuando (= participando) e

\footnotetext{
${ }^{3}$ MARINONI, Luiz Guilherme; MITIDIERO, Daniel. Comentários ao Código de Processo Civil, artigos 10 ao 69. (Coleção Comentários ao Código de Processo Civil, V.1, coordenação Luiz Guilherme Marinoni, Sérgio Cruz Arenhart, Daniel Mitidiero), São Paulo: Editora Revista dos Tribunais, 2016, p. 83-86.
} 
interferindo (= deliberando) no processo ao efeito de construírem a composição do conflito, restando ao juiz uma função de condução, orientação, promoção da composição, fiscalização e, por derradeiro, aí sim com força de império, de chancela da composição, seja homologando autocomposição, seja decidindo o mérito em favor de um ou de outro litigante, quando necessário. Acima de tudo, isso representa a mais autêntica manifestação de cidadania. Democracia no processo pressupõe participação ativa (= poder de influenciar no resultado) de todos que integram a relação processual.

Não é por outra razão que sempre se defendeu na doutrina a participação da cidadania no poder político como forma de concretizar a democracia. Nesse sentido, Rogério Gesta Leal afirma que a esfera política e individual integra um universo maior e mais amplo que representa a sociedade como um todo, consagrando a ideia de soberania popular ${ }^{4}$, o que já representa um passo a mais. De sorte que a participação do cidadão vai além da mera democracia participativa - que por si só já reformula o conceito pretérito de democracia representativa ${ }^{5}$, nitidamente em crise, mas nem por isso dispensável, agregando também a ideia de democracia deliberativa. Participar é decidir ou então a participação é meramente formal, insuficiente, mero expediente de cena, não atendendo ao desiderato maior, a construção de uma democracia real. $\mathrm{O}$ tema, tradicionalmente voltado para a esfera do Poder Executivo e do Poder Legislativo, o que não é objetivo deste trabalho, deve igualmente ser compreendido no âmbito do Poder Judiciário e de sua função política de pacificação social, com reflexos diretos sobre o paradigma da jurisdição, num primeiro momento compreendida como jurisdição pública, a ser prestada pelo Estado, mas estendendo-se igualmente a outras formas legítimas de solução dos conflitos de interesses.

Dizendo de outra forma, a democracia é cláusula pétrea também para a jurisdição, seja ela pública ou privada.

Quanto à jurisdição pública, indispensável, no ponto, registrar que o devido processo como garantia constitucional consagrada pela Constituição de 1988 encontra sua legitimação no controle do poder, ao qual também o Judiciário - e não apenas o Legislativo e o Executivo - está afeito. Nesse sentido, o devido processo encontra seu conteúdo na indispensabilidade do juiz natural, no contraditório e direito à defesa, na duração

\footnotetext{
${ }^{4}$ LEAL, Rogério Gesta. Estado, administração pública e sociedade: novos paradigmas. Porto Alegre, Livraria do Advogado Ed., 2006, p. 21-22.

${ }^{5}$ Para constar, colaciona-se lição de Jorge Miranda sobre o modelo de democracia representativa, muito mais voltada para o exercício dos poderes legislativo e executivo, assentado nas seguintes pilastras: "a) possibilidade ter o povo, sujeito do poder, uma vontade, actual ou conjectural, jurídica e politicamente eficaz. b) O reconhecimento, por motivos técnicos e materiais, da impossibilidade de o povo governar e, por isso, como sucedâneo, a necessidade de representação política. c) A concorrência da vontade do povo, manifestada pelo colégio de todos os cidadãos com direitos políticos, com a vontade manifestada pelos órgãos governativos de caráter representativo de caráter representativo. d) A responsabilidade política dos governantes, titulares desses órgãos, através do cumprimento dos deveres constitucionais relativos ao exercício dos seus cargos e do dever de informação do povo e, especificamente, através da eleição geral do termo de mandato, de eleições parciais durante este ou de referendo (MIRANDA, Jorge. Formas e sistemas de governo. Rio de Janeiro: Forense, 2007, p. 47-48). Por certo não é este modelo de democracia no processo que neste trabalho está se defendendo, embora o tema mereça, por sua relevância relativamente às instituições que compõem o Poder Judiciário, pesquisa própria
} 
razoável, no exercício probatório, nas decisões motivadas - que devem levar em conta todos os argumentos deduzidos pelas partes -, na pluralidade de instâncias, na previsão de tutelas provisórias em contrapartida à tutela definitiva, e no instituto da coisa julgada, garantia da indiscutibilidade e imutabilidade do que ao final foi decidido. E para que essas condições se materializem, indispensável a efetiva participação daqueles que são os destinatários da prestação jurisdicional, as partes, os sujeitos de direito. Participação material e deliberação, com influência na solução final. Ou a democracia estará ausente!

Já a tutela judicial efetiva, que segundo Francisco Chamorro Bernal guarda no mínimo quatro dimensões, a saber: (a) acesso à jurisdição; ao processo e às instâncias recursais; (b) proibição constitucional à ausência de defesa; (c) obtenção de uma resolução que componha o conflito; e (d) efetividade na prestação jurisdicional ${ }^{6}$, indiscutivelmente consagrada na Constituição como cláusula pétrea - na medida em que o acesso à justiça não se esgota nem pode se esgotar tão somente na provocação do Judiciário - reclama, para sua materialização, não só os mecanismos que concretizam o acesso à justiça, a exemplo da exigibilidade da presença do advogado na administração da justiça do caso concreto, da disponibilização pelo Poder Executivo de órgãos de Defensoria Pública, do benefício da gratuidade, como também a resolução adequada em tempo razoável e o efetivo cumprimento da sentença, assegurando o ordenamento jurídico os mecanismos processuais e materiais para a viabilização de todas essas fases do processo. Trata-se de instrumentos e mecanismos que dão sustentação à efetiva participação e à democrática composição da lide.

Caminha-se, nesse sentido, para um processo civil capaz de efetivamente construir a adequada solução para o conflito, destacando Fábio Lima Quintas depois de mencionar as formas alternativas e consensuais do litígio, estimuladas pelo novo Código:

Na verdade, esse novo regime põe em evidência uma nova perspectiva para compreender o que significa o escopo da jurisdição de alcançar a pacificação social e dirimir conflitos, qual seja a de obter o "tratamento adequado dos conflitos de interesses no âmbito do Poder Judiciário" (para utilizar a expressão da Res. CNJ 125, de 2010) 7.

Da discussão, em passado recente, do acesso à justiça, da instrumentalização do processo, da constitucionalização do processo, da efetividade e tempestividade processual - conquistas que foram agregando qualidade ao processo regulamentado na lei e praticado na vida forense e das quais não se pretende abdicar evolui-se para o debate contemporâneo da solução adequada dos conflitos. E é nesse espaço que se pretende incluir a discussão sobre a autocomposição judicializada conforme audiência do art. 334 do CPC de 2015.

\footnotetext{
${ }^{6}$ BERNAL, Francisco Chamorro. La tutela judicial efectiva; derechos y garantías procesales derivados del artículo 24.1 de la Constitución. Barcelona: Bosch, Casa Editorial, S.A, 1994, p. 11-12.

${ }^{7}$ QUINTAS, Fábio Lima. Para que um novo Código de Processo Civil? Uma reflexão sobre os novos contornos da função jurisdicional, in REVISTA DE PROCESSO, vol. 256, junho, 2016, p. 311.
} 


\section{A SOLUÇÃO CONSENSUAL DOS CONFLITOS E AS NORMAS FUNDAMENTAIS DO PROCESSO CIVIL}

O novo Código de Processo Civil instituiu, a partir do Livro I que cuida das normas processuais civis e, mais precisamente, no primeiro capítulo, ao contemplar normas fundamentais do processo civil, a constitucionalização do processo civil, modelo que de há muito a comunidade jurídica vinha reivindicando.

Entre as normas fundamentais elegidas nos primeiros doze artigos, ganha destaque, para o propósito destas reflexões, o disposto no art. $3^{\circ}$, em cujo caputse reedita a cláusula do acesso à justiça, vedando-se a exclusão da apreciação jurisdicional de ameaça ou lesão a direito e dispondo expressamente os respectivos parágrafos:

$\$ 2^{\circ} \mathrm{O}$ Estado promoverá, sempre que possível, a solução consensual dos conflitos.

$\$ 3^{\circ}$ A conciliação, a mediação e outros métodos de solução consensual de conflitos deverão ser estimulados por juízes, advogados, defensores públicos e membros do Ministério Público, inclusive no curso do processo judicial.

Tais disposições vêm ao encontro da constitucionalização do processo, do devido processo e da solução adequada do conflito, na medida em que se mantém hígida a participação das partes, apoiadas pelos órgãos e agentes públicos responsáveis pelo processo e pela composição da lide, estimulando-se que esta solução venha pela via consensual, ratificada a autonomia da vontade equilibrada.

Mais uma vez se socorre da doutrina de Luiz Guilherme Marinoni e Daniel Mitidiero ${ }^{8}$, ao descorrerem sobre a justiça multiportas:

No paradigma do Código Buzaid, a mensão à tutela dos direitos remetia o intérprete imediatamente à tutela jurisdicional dos direitos, pressupondo-se a jurisdição como único meio possível - ou pelo menos como meio larguissimamente dominante - para solução de disputas judiciais. Nesse particular, o Código de 2015 promoveu uma "inversão dos paradigmas na justiça", sendo apontada essa circunstância pela doutrina como uma de suas mais importantes e profundas inovaçōes (o grifo é nosso).

Em sequência, alertam ainda os autores citados, que o Código não fala em meios alternativos, mas em métodos de solução consensual de conflitos, reconhecendo o seu contingenciamento, pois nem sempre será o caminho mais indicado, daí porque defender a ideia de que o sistema judicial comporta não uma, mas várias portas, ao fito de superação dos conflitos.

Inúmeros são os dispositivos do novo estatuto processual que guardam aderência a esta norma fundamental: a busca da solução do conflito por vias consensuais, seja a mediação, a conciliação ou qualquer outro método adequado, tais como o art. 139, inciso V (é dever do juiz promover a qualquer tempo a autocomposição); arts. 165 a 175 (disposições que regulam os centros judiciários, prevendo as cláusulas condutoras da conciliação e da mediação); art. 174 (criação de câmaras de mediação e conciliação no âmbito administrativo). Estende-se, outrossim, a proposta do consenso, quando frustrada a autocomposição do conflito, para a condução do processo

\footnotetext{
${ }^{8}$ MARINONI, Luiz Guilherme; MITIDIERO, Daniel, ob. cit, p. 121.
} 
adversarial, a exemplo dos arts. 190 e 191 (negócio jurídico processual); art. 357, \$ 2 (delimitação consensual das questões de fato e de direito); art. 359 (conciliação na audiência de instrução e julgamento); art. 373, $\$ \$ 3^{\circ}$ e $4^{\circ}$ (convenção sobre o ônus da prova); e claro, a audiência preliminar do art. 334, que é o próprio objeto deste trabalho.

A ideia da autocomposição - no todo ou em parte - põe-se como alternativa à imposição violenta, cogente e imperial do decidir advinda do processo adversarial e da sentença, reconhecendo Luís Eduardo Simardi Fernandes que o novo Código valoriza a pacificação social obtida pela solução consensual, estabelecendo como dever de função aos juízes, advogados, defensores, membros do Ministério Público, o estímulo aos meios consensuais, como a conciliação e a mediação?.

Indo além, poder-se-ia, frente a esse universo, afirmar que se agrega mais um princípio ao rol dos princípios informadores do processo civil, no caso, o princípio da consensualidade, como uma nova visão das formas de composição ou superação dos conflitos.

E exatamente para materializar a composição consensual, o Código estabelece uma audiência preliminar, que tanto poderá ser de conciliação ou mediação, conforme dispõe o art. 334: se a petição inicial preencher os requisitos essenciais e não for o caso de improcedência liminar do pedido, o juiz designará audiência de conciliação ou de mediação com antecedência mínima de 30 (trinta) dias, devendo ser citado o réu com pelo menos 20 (vinte) dias de antecedência, objeto específico deste trabalho, mais adiante a ser enfrentado.

Marcelo Abelha destaca, sobre as normas fundamentais que guardam natureza constitucional e as regras de técnica processual, o permanente dever de entre si dialogarem, a saber:

É preciso entender que o artigo $1^{\circ}$ do CPC determina que o Estado juiz, durante todo o itinerário processual, do recebimento da petição inicial até a prolação da sentença ou se for o caso até a efetivação do título judicial ou extrajudicial, cumpra em concreto a orientação ali contida. Cada norma processual aplicada ao longo do processo deve ser interpretada, aplicada, disciplinada e organizada de acordo com os valores fundamentais da CF/1988. O magistrado deve fazer um controle de constitucionalidade em cada caso concreto, em cada situação particular enfrentada ao longo do processo para que desta forma atenda aos fins sociais e às exigências do bem comum, resguardando e promovendo a dignidade da pessoa humana, observando a proporcionalidade, a razoabilidade, a legalidade, a publicidade e a eficiência (artigo $\left.8^{\circ}\right)^{10}$.

Considerando que o primeiro capítulo do Código trata exatamente dessas normas fundamentais, é como se fôssemos dividir o Código em duas partes: os primeiros 12 artigos, compondo uma das partes, e a segunda, englobando os demais 1.060 artigos, dispositivos esses a serem compreendidos à luz dos primeiros doze. Um diálogo entre as regras processuais e as normas fundamentais do processo, em apertada síntese.

Importa ainda ponderar que a introdução da autocomposição dos conflitos de interesse encontra

${ }^{9}$ FERNANDES, Luís Eduardo Simardi, in DELLORE, Luiz et al. Teoria Gera do processo contemporâneo, São Paulo: Atlas, 2016, p. 12-13. 
fundamento direto com o dogma constitucional da democracia e a concretização da ordem jurídica, em busca de uma efetividade que passa a ser dever de todos. Nesse fio, para Humberto Theodoro Júnior, ao tratar dos equivalentes jurisdicionais, a autocomposição é aquela construída exclusivamente pelas partes, sem qualquer intervenção de um terceiro, a exemplo da desistência da ação, a renúncia e a transação, enquanto que a heterocomposição reclama a presença de um terceiro (agente público ou privado), onde inclui a jurisdição estatal, a arbitragem, a conciliação e a mediação, concluindo o jurista que a classificação como posta é de pouca ou nenhuma relevância, pois o que efetivamente importa é que o conceito, a compreensão e o papel desses equivalentes serão os mesmos, produzindo a composição do conflito ${ }^{11}$. Assim, entre a jurisdição pública prestada em sentença oriunda de processo adversarial ou a conciliação levada a efeito entre as partes, extra ou judicialmente, há um ponto em comum: ambas alcançam o mesmo desiderato, concretizar a ordem jurídica respeitando a Constituição.

Não há um consenso na doutrina, entretanto, em classificar as chamadas autocomposição ou meios alternativos de resolução de disputas. Para Gustavo Osna, por exemplo, diferentemente da proposta de Humberto Theodoro Júnior, a heterocomposição se realiza essencialmente pela jurisdição (pública ou privada), onde o responsável pela decisão é um terceiro, enquanto que a autocomposição abrange a conciliação e a mediação ${ }^{12}$. No mesmo caminho, Marco Félix Jobim declina as diferentes versões doutrinárias sobre as formas de autocomposição, arrolando-as, a despeito das divergências, entre a desistência, renúncia, submissão e transação ${ }^{13}$.

De qualquer sorte, sem embargo de eventuais enfoques distintos, o fato é que este alinhamento entre jurisdição e autocomposição tem em si um elemento revelador e só se sustenta teoricamente se o olhar sobre o conflito de interesses, o processo e a atividade judicial passe a ser um olhar constitucional, onde o que revela é a concretização dos direitos fundamentais e da ordem jurídica e a atuação das partes se dê de forma participativa e deliberativa. Ser parte num processo é exercício de cidadania, é afirmar a democracia.

Nos limites deste trabalho, algumas ponderações sobre a mediação e a conciliação, que serão tratadas como formas específicas de autocomposição, considerando o comprometimento de enfrentar a audiência do art. 334 do CPC/2015.

\footnotetext{
${ }^{10}$ ABELHA, Marcelo. Manual de direito processual civil, 6a ed., Rio de Janeiro: Forense, 2016, p. 48-49.

${ }^{11}$ THEODORO JÚNIOR, Humberto. Curso de Direito Processual Civil: teoria geral do direito processual civil, processo de conhecimento e procedimento comum, 57a ed., Vol. I, Rio de Janeiro: Forense, 2016, p. 123.

${ }^{12}$ OSNA, Gustavo. A "audiência de conciliação ou mediação" no novo CPC: seis (breves) questões para debate, in REVISTA DE PROCESSO, vol. 256, junho, 2016, p. 352.

${ }^{13}$ JOBIM, Marco Félix. Teoria, História e Processo: com referências ao CPC/2015, Porto Alegre: Livraria do Advogado Editora, 2016, p. 79-81.
} 


\section{A MEDIAÇÃO E A LEI N. 13.140, DE 26 DE JUNHO DE 2015}

O instituto da mediação veio recentemente regulado pela Lei n. 13.140/2015, publicada em data de 29/06/2015, cujo prazo de vigência foi de 180 (cento e oitenta) dias após sua publicação, isto é, dia 26 de dezembro e, portanto, entrando em vigor antes mesmo da vigência do novo Código de Processo Civil.

Indispensável, portanto, conciliar os dois estatutos - a Lei da Mediação e o Código de Processo Civil em especial no que diz com a audiência preliminar do art. 334 do CPC/2015.

Na lição de Humberto Dalla Bernardina de Pinho e Ludmilla Camacho Duarte Vidal,

(...) a guinada legislativa instituindo a política pública de estímulo às soluções extraídas do consenso veio com a Res. 125/2010 do Conselho Nacional da Justiça (CNJ), sendo essa incrementada a partir do advento do Código de Processo Civil de 2015, bem como do

E prosseguem Marco Legal da Mediação.

Os diplomas retro possuem três palavras de ordem: adequação, flexibilização e eficiência. Sob o ponto de vista dos graus da escala de aperfeiçoamento do serviço jurisdicional, a adequação é compreendida como o patamar mais elevado em relação ao degrau ocupado pela efetividade, servido para auxiliar as partes na escolha do caminho disponível que corresponda, satisfatoriamente, aos interesses da causa ${ }^{14}$.

Sem pretender aprofundar a compreensão e a reflexão sobre o instituto da mediação - até porque foge ao objeto deste trabalho - ponto fundamental a ser destacado vem no parágrafo único do art. $1^{\circ}$ da lei de regência: o mediador não detém poder de decisão. São as partes que devem encontrar a solução consensual sobre a controvérsia, ou seja, o poder de decisão lhes compete. Por isso mesmo princípio condutor da mediação, entre outros, é a autonomia da vontade das partes, que para tanto devem guardar paridade, o que desagua em outro princípio do instituto, que é a isonomia. Tais vetores encontram-se expressamente previstos no art. $2^{\circ}$, da Lei $\mathrm{n}$. 13.140/2015. Como corolário, o $\$ 22^{\circ}$ deste dispositivo assegura que “ninguém será obrigado a permanecer em procedimento de mediação". Ou seja, basta que um dos conflitantes rejeite a mediação e ela estará prejudicada.

Outro traço fundamental é que a mediação deve ter por objeto conflito que verse sobre direitos disponíveis ou sobre direitos indisponíveis que admitam transação (art. 3º). Ou seja, há conflitos que não guardam aderência à autocomposição, especialmente aqueles que integram o patrimônio jurídico da pessoa humana como os direitos de personalidade. Forçoso concluir que a mediação não é solução para todos os conflitos de interesses, ainda que sua adoção possa se expandir para um sem número de situações, antes impensadas de serem resolvidas à luz da autocomposição, como o próprio art. 174 do CPC/2015 que impõe à União, aos Estados, ao Distrito Federal e aos Municípios o dever público de criar câmaras de mediação e conciliação, voltados esses órgãos à solução consensual de conflitos no âmbito administrativo, valendo-se 
inclusive do termo de ajustamento de conduta, instrumento criado pela Lei da Ação Civil Pública.

É ainda Dalla Bernardina e Ludmilla Vidal que atestam para a existência de um movimento universal incentivando e valorizando as técnicas consensuais ${ }^{15}$, num franco reconhecimento da evolução cultural participativa, onde o diálogo, a cooperação e o consenso são determinantes para a pacificação dos conflitos, o que o Direito brasileiro vem chancelando nesses dois estatutos.

O estatuto da mediação cria, por outro lado, a figura de mediadores judiciais - o que encontra harmonia com as disposições do Código de Processo ao prever os centros judiciários de solução consensual de conflitos - e a de mediadores extrajudiciais, que há de ser objeto de contrato, nos termos dos arts. 21 a 23 da respectiva lei de regência, ambas as atuações, porém, voltadas para a definitividade do conflito: título executivo extrajudicial ou título executivo judicial, conforme o caso (art. 20, parágrafo único).

Sem adentrar no procedimento específico da mediação, vale ressaltar que desde logo o estatuto prevê a realização de sessões sucessivas (arts. 14 e 18), até porque se trata de um processo onde se trabalha psicologicamente a assimilação do próprio conflito, de sua origem e extensão, das possíveis consequências, que cumpre às partes irem construindo até chegarem a um denominador comum. A mediação não objetiva um vencedor, mas que não haja perdedores, orientando-se não pelo critério da justiça, mas sim do interesse. Também o CPC, embora tratando a audiência preliminar indistintamente, de conciliação ou de mediação, prevê no $\$ 2^{\circ}$ do art. 334 a sequência de mais de uma sessão, limitando, porém, as respectivas realizações a 2 (dois) meses a contar da primeira sessão. Aqui, torna-se evidente, a preocupação com a tempestividade do processo.

Em apertadas linhas, a despeito da convergência de alguns dispositivos, de concluir que não há tratar pelos mesmos cânones a mediação e o processo judicial, embora se perceba uma forte tendência de judicialização da mediação, tanto na Lei n. 13.140/2015 como no próprio Código de Processo Civil, tema que merece espaço próprio para melhor exploração. Se, de um lado, temos dispositivos que convergem entre os dois diplomas legais, de outro temos contrariedades que são relevantes e devem ser questionadas.

\section{A AUDIÊNCIA DE MEDIAÇÃO NO ART. 334 E A COGENCIA NA SUA REALIZAÇÃO E PARTICIPAÇÃO: CRÍTICAS}

Como preâmbulo, merece destaque a compreensão de que a audiência preliminar vem ao encontro da norma fundamental do art. $3^{\circ}$ e seu $₫ 3^{\circ}$ do novo estatuto e recepciona força constitucional porque estimula as formas alternativas de solução consensual a viabilizar a concretização dos direitos fundamentais e a própria

\footnotetext{
${ }^{14}$ PINHO, Humberto Dalla Bernardina de; VIDAL, Ludmilla Camacho Duarte. Primeiras reflexões sobre os impactos do novo CPC e da Lei de Mediação no Compromisso de Ajustamento de Conduta, in REVISTA DE PROCESSO, vol. 256, junho, 2016, p. 385-386.

${ }^{15}$ Idem, idem, p. 399.
} 
manutenção da ordem jurídica.

A principal técnica utilizada, para alcançar o desiderato a que se propõe, é o chamamento do réu para a audiência sem o ânimo da adversariedade, oportunizando o encontro das partes, autor e réu, devidamente representados por seus advogados, mas sem a instauração, ainda, do contraditório, o que decorre do disposto no art. 335, inciso I, que oportuniza a contestação no prazo de 15 (quinze) dias a ser computado após a realização da audiência de conciliação ou mediação ou da última sessão uma vez frustrada a autocomposição. A solução adotada é, de um lado, meritória porque, pelo menos em princípio, sem a oferta da contestação, as partes estão mais desarmadas e sucessíveis de conversarem e de encontrarem um denominador comum, mas de outro não se pode olvidar que o réu fica numa situação privilegiada, porque conhece as teses e provas documentais que o autor maneja, enquanto que esse desconhece as teses e provas da defesa. De qualquer sorte, independentemente do peso dados às vantagens/desvantagens da audiência preliminar, o fato é que a doutrina já aponta críticas a essa disposição, e não sem razão porque não desgarram da realidade forense, presente o risco de haver o manejo do procedimento instaurado para procrastinar o feito, valendo-se dessa regra para estender no tempo a instauração da fase cognitiva:

De fato, considerando que no CPC de 1973 o interstício para a apresentação da contestação tem como termo inicial a juntada aos autos da respectiva citação do réu, o prazo previsto no novo CPC poderá ensejar um trâmite inicial demasiado longo, até porque há expressa menção no caput do art. 334, de que a cerimônia deverá ser aprazada com 'antecedência mínima de 30 (trinta) dias, devendo ser citado o réu com pelo menos 20 (vinte) dias de antecedência'.

E prosseguem os articulistas referendados:

Ademais, mesmo que se admita o agendamento da audiência com um prazo não tão largo, não se pode olvidar as dificuldades operacionais advindas do ato de citação, com o que a adequação dos dois prazos previstos no dispositivo legal poderá ensejar, não raras vezes, impropriedades, sendo necessário o reagendamento da data originalmente prevista ${ }^{16}$

De qualquer sorte, o texto do art. 334 do CPC/2015, como está posto, sugere a cogência de uma audiência preliminar, independentemente da demanda posta, que poderá ser ou de mediação ou de conciliação. Neste capítulo, atentar-se-á preponderantemente à audiência de mediação, sem prejuízo de algumas referências à via da conciliação, alternativa viável aos eventuais obstáculos à instauração da mediação.

Esta cogência decorre do disposto no $₫ 4^{\circ}$ do mesmo artigo, que contempla duas hipóteses para a sua não ocorrência: a) quando ambas as partes manifestarem desinteresse na autocomposição, e $b$ ) quando não se admitir a autocomposição.

Para a primeira hipótese, cumpriria ao autor desde logo expressar seu desinteresse na petição inicial, conforme dispõe o art. 319, inciso VII, do CPC/2015, e ao réu, quando citado, apresentar petição no prazo de 10 
(dez) dias de antecedência, ou seja, a audiência já estaria designada, até porque integraria o despacho inicial de recebimento da petição inicial $\left(\$ 5^{\circ}\right)$.

Por outro lado, o $₫ 8^{\circ}$ considera ato atentatório à dignidade da justiça, sancionado com multa de até dois por cento da vantagem econômica pretendida ou do valor da causa, revertida em favor da União ou do Estado, o não comparecimento injustificado tanto do autor como do réu. Não trata o dispositivo da hipótese fática em que os dois lados - autor e réu - poderão não se fazer presente na audiência preliminar, sem qualquer justificativa e independentemente de seu silêncio prévio quanto à resistência à autocomposição, abrindo-se um espaço para a interpretação judicial, que tanto poderá inclinar-se para entender o não comparecimento como manifestação tácita - que nos parece mais adequada - no desinteresse de autocomposição, como concluir pelo duplo enquadramento na previsão do parágrafo, sancionando ambas as partes.

No alinhamento da cogência, a ENFAM, em seminário realizado sobre o novo CPC, editou enunciados, entre os quais o de n. 61, assim redigido:

Somente a recusa expressa de ambas as partes impedirá a realização da audiência de conciliação ou mediação prevista no art. 334 do CPC/2015, não sendo a manifestação de desinteresse externada por uma das partes justificativa para afastar a multa de que trata o art. $334, \$ 8^{\circ}$

Há, portanto, uma convergência entre o disposto na lei e o entendimento prévio manifestado por órgão da magistratura para se ter a audiência preliminar como cogente. Considerando que a lei não distingue se a audiência será de mediação ou de conciliação, aplica-se tal cogência a ambas as hipóteses. Aqui reside a primeira crítica a ser oportunamente deduzida.

Voltando, ainda, às hipóteses de dispensa da audiência prévia, tem-se o segundo caso, relativo à não admissão de autocomposição. Como bem destaca Fredie Didider $\mathrm{Jr}^{17}$, não há que confundir direitos indisponíveis com impossibilidade de autocomposição, exemplificando o jurista como hipótese incidente aquelas em que o Poder Público é parte no conflito e não está autorizado para a composição, ainda que o novo estatuto processual também estimule a autocomposição em processos administrativos ou judiciais, em que for parte o poder público, como antes já sinalizado. Pode-se agregar, ainda, conflitos que digam com direitos de personalidade, como demanda que envolva o nome da parte ou o estado de capacidade. Isso sob o aspecto de vedação formal. Mas pode se levar em conta que determinadas demandas não estão materialmente afeitas à autocomposição. Cita-se aqui, como exemplo, ações repetitivas, responsáveis, ainda que não exclusivamente, pelo fenômeno da numerosidade de processo, fenômeno este que, por sua vez, é o principal responsável pela morosidade na atuação do Poder Judiciário e, por via reflexa, na inefetividade da prestação jurisdicional. O conflito nesses casos é

\footnotetext{
16 RIBEIRO, Cristiana Zugno Pinto; FISCHER, Roger. A audiência de conciliação ou de mediação do novo CPC, in Procedimento comum: da petição inicial à sentença à luz do novo Código de Processo Civil, TESHEINER, José Maria; MACEDO, Elaine Harzheim; THAMAY, Rennan Faria Krüger (Coord.), Curitiba: Juruá, 2015, p. 59.

${ }^{17}$ DIDIER JR., Fredie. Curso de Direito Processual Civil, V. 1, Salvador: Editora JusPodivm, 2015, p. 625.
} 
subjetivamente muito maior que eventual controvérsia individual, pois, ainda que se alcance uma composição consensual em relação àquele sujeito individualmente posto na relação processual, o conflito se repete para além daquele processo pontual, fazendo-se presente a necessidade de uma composição coletiva, seja consensual, seja por força de decisão judicial, que atinja toda a coletividade. Não é por outra razão que o novo CPC adotou, com todas as letras, o precedente vinculante para demandas tais. Há de se indagar se, efetivamente, vem ao encontro do interesse público, nesses casos, eventual transação pontual, que até pode, ainda que de difícil sucesso, alcançar o interesse individual da parte, mas jamais a defesa da própria ordem jurídica, incontestavelmente entregue ao Poder Judiciário e que as demandas repetitivas põem à nu, considerando a pluralização de seus legítimos interessados, estejam ou não participando de outras ações idênticas.

Contudo, independentemente desta segunda hipótese de não realização da audiência preliminar, o fato é que a cogência de realização de audiência de mediação, prevista para a mais absoluta generalidade de hipóteses de conflito, vem ao desencontro dos princípios que regem a mediação, em especial a isonomia entre as partes, a autonomia da vontade das partes e a busca do consenso.

Assim, a Lei n. 13.140/15 dispõe:

Art. 2으 A mediação será orientada pelos seguintes princípios:

(...)

$\mathrm{V}$ - Autonomia da vontade das partes;

(...)

E mais adiante:

\$2ํNinguém será obrigado a permanecer em procedimento de mediação.

Art. 21. O convite para iniciar o procedimento de mediação extrajudicial poderá ser feito por qualquer meio de comunicação e deverá estipular o escopo proposto para a negociação, a data e o local da primeira reunião.

Parágrafo único. O convite formulado por uma parte à outra considerar-se-á rejeitado se não for respondido em até trinta dias da data de seu recebimento.

De sorte que não só a lei estabelece a autonomia da vontade como princípio norteador da mediação como ainda assegura que ninguém permanecerá em procedimento de mediação. Na mediação provocada, a parte adversa será convidada - e não citada - para comparecer e iniciar o procedimento, e o simples não atendimento a este convite acusa a não-aceitação da mediação como forma de compor conflitos, pondo por terra a mediação.

Já para o CPC, a regra é outra, havendo que ter dupla manifestação, do autor e do réu, para que não se instaure a mediação como opção para a autocomposição, impondo-se, pois, ao réu a instauração do procedimento mesmo externando, de forma isolada, sua discordância. De indagar qual o sucesso esperado nesses casos, o que só o tempo poderá responder. Este é um ponto de divergência entre os dois estatutos, ainda não suficientemente superado pela doutrina. 


\section{Generalização na previsão e insuficiência de critérios para definição entre mediação e conciliação no art. 334}

O artigo 334 do CPC/2015 abstrai qualquer inclinação, seja para a mediação, seja para a conciliação, mostrando-se genérico e virtual, sem qualquer comprometimento com a concretude do conflito subjacente ou mesmo em relação à estrutura com a qual a unidade forense possa contar para seguir o caminho da autocomposição, considerando o disposto no art. 165 do CPC/2015, responsável pela criação de centros judiciários de solução consensual de conflitos. Impõe, porém, ao juiz o encaminhamento das partes para uma dessas formas de autocomposição, remanescendo para melhor orientação do julgador o disposto nos parágrafos do art. 165:

E:

$\$ 2^{\circ} \mathrm{O}$ conciliador, que atuará preferencialmente nos casos em que não houver vínculo anterior entre as partes, poderá sugerir soluções para o litígio, sendo vedada a utilização de qualquer tipo de constrangimento ou intimidação para que as partes conciliem.

$\$ 3^{\circ} \mathrm{O}$ mediador, que atuará preferencialmente nos casos em que houver vínculo anterior entre as partes, auxiliará aos interessados a compreender as questões e os interesses em conflito, de modo que eles possam, pelo restabelecimento da comunicação, identificar, por si próprios, soluções consensuais que gerem benefícios mútuos.

Duas observações, a primeira diz com o uso reiterado da palavra "preferencialmente", isso porque, a rigor, qualquer conflito pode ser mediado ou submetido à conciliação. Não há regra nem material nem processual a determinar a opção entre um ou outro procedimento. Em princípio, estimula-se a mediação para aquelas situações em que as partes prosseguirão se relacionando fática e juridicamente independentemente do conflito instaurado, enquanto que a conciliação seria um caminho razoável para superar um conflito pontual e isolado na vida dos conflitantes. A segunda, aí sim comparecendo a distinção, diz com o procedimento a ser adotado. $\mathrm{Na}$ conciliação, o conciliador intervém, propõe, oferta soluções e alternativas; na mediação essas devem aflorar a partir das próprias partes. São técnicas distintas de se alcançar a autocomposição.

Ou seja, o juiz ao receber a petição inicial não conta com muitos elementos para orientar o próximo passo a ser adotado: encaminha as partes para a mediação ou para a conciliação? São inúmeros os fatores a influenciar essa decisão. Por certo a orientação acima mencionada, mas também a própria estrutura da unidade judiciária poderá ser decisiva. A existência, a proximidade, a regular instalação, o número de conciliadores e mediadores à disposição do juízo deverão ser fatores determinantes, orientando sua escolha.

O que preocupa é que o art. 334 não se torne instrumento de tentativa de superar o fenômeno da numerosidade de processos, que atingiu no ano de 2015 o número fabuloso de 9 (nove) dígitos ${ }^{18}$, aliviando-se a

$18 \mathrm{In}$ http://g1.globo.com/bom-dia-brasil/noticia/2015/09/processometro-vai-medir-processos-que-estao-na-fila-da-
justica.html, acessado em 14.08.16, referindo dados de 2015 onde o número de processos acumulados no Poder Judiciário alcança vol.10, nº. 03, Rio de Janeiro, 2017.pp. 2060-2083 
pauta de processos litigiosos, mas esquecendo-se o legislador processual que os principais responsáveis pelo excesso de litigiosidade são os conflitos repetitivos, envolvendo grandes fornecedores de crédito, produtos e serviços, e o próprio poder público, de todos, os menos sensíveis à autocomposição, porque atuam no mais das vezes movidos pela estatística e estratégias negociais e não pelos critérios de justiça. Igual preocupação vem de Gustavo Osna, ao destacar que o recurso às vias de autocomposição não podem constituir "válvula diversa da jurisdição estatal" ${ }^{19}$, porquanto consistem um espaço próprio e relevante, com vantagens e benefícios próprios.

Por outro viés, a superação da cogência posta no art. 334 pode ensejar a previsão de uma audiência preliminar de conciliação, a ser realizada pelo próprio juiz (de lembrar a realidade judiciária em todos os confins do território nacional e as enormes dificuldades de organização judiciária em compor tais quadros), até porque a conciliação é atividade ínsita à prestação jurisdicional, de velha tradição no processo civil.

Cediço que a mediação - importante espaço democrático de autocomposição de conflitos - não representa remédio para todos os males que afetam à vida em sociedade e ao Poder Judiciário, sobrecarregado de demandas, voltando-se mais para determinadas classes de conflitos, não para a generalização de feitos que assola os foros de primeiro grau de jurisdição. Representa, sim, um marco democrático na composição de conflitos, mas utilizar a mediação para sanar as deficiências administrativas, de organização judiciária ou do próprio sistema processual, que não conta com freios ao abuso da litigiosidade (outro problema que não pode ser ignorado), não é a melhor solução, mais representando uma troca de seis por meia dúzia.

Nesse fio, a mediação, sem embargo de que qualquer conflito em tese pode ser mediado, encontra rico espaço de atuação e de possível sucesso em demandas que versem sobre direito de família, direito sucessório, conflitos de convivência entre parentes, especialmente quando envolvem idosos, vizinhança e condomínio. Pressupõe-se, nesses casos, a continuidade nas relações independentemente do conflito instaurado. As controvérsias que envolvem o direito consumerista também podem ser solucionadas via mediação, especialmente quando pontuais, individualizadas, o mesmo se estendendo a contratos e até a ressarcimentos com base no ato ilícito, ainda que aqui as partes conflitantes, em princípio, esgotem suas relações, sob o aspecto temporal, na relação jurídica litigiosa. Mas nem por isso situações tais são avessas ao caminho da autocomposição via conciliação, que se mostra também pertinente. Esse o dilema a ser vencido pelo juiz já ao receber a petição inicial, pois é nesse momento processual que se há de definir a audiência e a forma de autocomposição.

Em síntese, o remeter as partes para a mediação ou para a conciliação é uma primeira indagação que se põe, mas não esgota as incertezas. E se remetida as partes para a mediação, quando mais compatível seria a conciliação, ou vice-versa, não representaria isso uma perda de tempo, em dissonância com o propósito de obter-se a solução

mais de 105.000.000. Resultados semelhantes podem ser obtidos, com mais precisão, na pesquisa junto ao CNJ cujos relatórios de "Justiça em Números" surpreendem.

${ }^{19}$ OSNA, Gustavo, ob. cit., p. 353. 
integral do mérito em prazo razoável (art. 4º, CPC/2015)? E remetendo para uma das vias as partes deixam entrever que o outro procedimento seria mais adequado? Comportaria às partes a escolha? Em qual momento? Petição inicial, por conta do autor? Na manifestação do prazo em 10 (dez) dias, valendo-se o réu não da resistência à autocomposição, mas optando por uma ou por outra via, em desacordo com a manifestação do autor? E, em havendo dissonância entre as partes, o que há de prevalecer?

Mais uma vez socorre-se do articulista Gustavo Osna que também conclui no mesmo sentido, acusando a falta de especificidade do novo Código, prevendo indistintamente a audiência de mediação e a de conciliação, trazendo fórmulas procedimentais idênticas para ambas ${ }^{20}$.

De sorte que se avolumam hipóteses de crise no processo que o art. 334 não tem o condão de afastar ou de impedir.

\section{Exigências de organização judiciária aptas a tornar a audiência de mediação (ou de conciliação) viável}

Muitos dos problemas com a efetiva e tempestiva prestação jurisdicional estão atrelados às dificuldades, comuns aos poderes públicos, que dizem com a infraestrutura de pessoal, numérica e qualitativamente preparada, para o exercício das respectivas funções típicas, seja para o exercício da judicatura, seja para os serviços de assessoramento que a judicatura exige ou ainda para a execução de todas as tarefas processuais, ínsitas às práticas cartorárias. A falta de magistrados e de servidores da justiça que sustentam a máquina do Poder Judiciário é flagrante e de todos conhecida, importante fator na crise do processo.

A partir desta constatação, o novo CPC, especialmente em seu art. 334, mostra-se, a par de seus méritos, distanciado da realidade administrativa do Poder Público e da profunda crise econômica em que o país está imerso, pressupondo que no dia seguinte à entrada em vigor do estatuto tudo estará preparado para fazer acontecer, pouco ou nada dialogando com os artigos 165 e seguintes,. Não é bem assim. A título de exemplo, quando da entrada em vigor da Lei n. 9.099/95, que instituiu a obrigatoriedade dos juizados especiais em todo o território nacional, foram necessários alguns anos para que efetivamente fossem implementados tais comandos e criadas e instaladas as respectivas unidades judiciárias. Não é diferente com a criação de centros judiciários de solução consensual de conflitos responsáveis pela realização de sessões e audiências de conciliação e mediação, que assessoram os juízes com a audiência preliminar do art. 334 do CPC/2015, a compor os órgãos auxiliares da justiça.

De Gustavo Osna vem a indagação, absolutamente legítima, considerando a realidade nacional, se é oportuno a criação de novas estruturas no âmbito do Judiciário, dando destaque aos custos inerentes a tais 
providências, bem como sua (in)compatibilidade ao momento econômico de estrangulamento fiscal ${ }^{21}$.

Também aqui a cogência pretendida há de ceder espaço frente à realidade da organização judiciária, cujas unidades nem sempre contarão com tais serviços à disposição. Se, de um lado, o juiz pode conduzir uma audiência prévia conciliatória, fazendo valer a regra da lei processual, o mesmo não é verdadeiro quanto a audiência de mediação: o juiz é órgão decisor, sustentado pelo poder jurisdicional que lhe é outorgado por força de sua investidura e nos termos da Constituição republicana, aí não embutida a função de mediador. Aliás, decidir e mediar são atividades incompatíveis e que mutuamente se excluem, tema que já foi explorado alhures.

Não há nenhuma incongruência lógica em o juiz conduzir uma conciliação, homologar o acordo e, oportunamente, se a tanto provocado, fazer valer pelas regras do cumprimento de sentença as cláusulas da transação.

O mesmo não vale para a atividade mediadora. A mediação, considerada tecnicamente, pode ser definida como:

Um processo autocompositivo segundo o qual as partes em disputa são auxiliadas por uma terceira parte, neutra ao conflito, ou um painel de pessoas sem interesse na causa, para auxiliá-las a chegar a uma composição. Trata-se de uma negociação assistida ou facilitada por um ou mais terceiros na qual se desenvolve processo composto por vários atos procedimentais pelos quais o(s) terceiro(s) imparcial(is) facilitam a negociação entre pessoas em conflito, habilitando-as a melhor compreender suas posições e a encontrar soluções que se compatibilizam aos seus interesses e necessidades ${ }^{22}$.

O mediador não exerce papel decisório, não influi nos termos da composição, daí o seu distanciamento da função judicial stricto sensu, sempre carregada pelo império. O mediador atua como interlocutor das partes em conflito, devendo manter-se imparcial, ter habilidade de comunicação para escutar e conversar com os conflitantes. Deve, por óbvio, conhecer as bases jurídicas da relação atritada, mas para além do conhecimento jurídico, deve ter uma boa compreensão dos direitos humanos, ter sensibilidade, captar aquilo que está muitas vezes no substrato do conflito e nem sempre é verbalizado. São, portanto, atividades incompatíveis - a de mediar e a de julgar, sem nenhum obstáculo que o juiz togado venha no futuro, se for o caso, conduzir o procedimento de cumprimento de sentença caso à mediação seja judicial e levada à homologação, ou, sendo extrajudicial, deságue num processo de execução, conforme dispõe o art. 20 e seu parágrafo único: o termo final de mediação, na hipótese de celebração de acordo, constitui título executivo extrajudicial e, quando homologado judicialmente, título executivo judicial. Não se confundem o procedimento da mediação ao efeito da autocomposição, seja judicial seja extrajudicial, e eventual procedimento de execução dos termos do acordo que tenha sido desrespeitado por uma das partes.

\footnotetext{
${ }^{20}$ OSNA, Gustavo, ob. cit, p. 358.

${ }^{21}$ OSNA, Gustavo, ob. cit., p. 361.

22 AZEVEDO, André Gomma (coord.). Estudos em Arbitragem, Mediação e Negociação, Vol. 3, Brasília: Grupos de Pesquisa, 2004, p. 313.
} 
Isso mostra, de um lado, a exigência de o Poder Judiciário investir nos órgãos auxiliares da justiça, compondo os centros que deverão contar com profissionais especializados e adequadamente preparados para as atividades de conciliar ou de mediar, mas de outro lado fica pendente a questão de disponibilidade de levar a efeito tais pautas, certamente de elevados custos.

O que se está a defender é uma harmonia maior entre o art. 334 e o art. 165 do CPC/2015 e o art. 24 da Lei de Mediação, esses, sim, convergindo para uma mesma orientação, até porque o tema é de organização judiciária. No ponto, a relativização do comando, remetendo a composição e organização para os respectivos tribunais e para o Conselho Nacional de Justiça, se faz presente no parágrafo único do art. 165, quando dispõe: a composição e organização do centro serão definidas pelo respectivo tribunal, observadas as normas do Conselho Nacional de Justiça, o que também está presente na Lei da Mediação, conforme art. 24 e seu parágrafo:

Os tribunais criarão centros judiciários de solução consensual de conflitos, responsáveis pela realização de sessões e audiências de conciliação e mediação, pré-processuais e processuais, e pelo desenvolvimento de programas destinados a auxiliar, orientar e estimular a autocomposição.

A composição e a organização do centro serão definidas pelo respectivo tribunal, observadas as normas do Conselho Nacional de Justiça.

O que em certa medida se divorcia de tais disposições é a imposição do art. 334, determinando de forma cogente o encaminhamento das partes para a audiência de mediação ou de conciliação. Hora, o day after já aconteceu, pois, o Código entrou em vigor no dia 18 de março de 2016. Mas haverá ainda um largo espaço de tempo para que se concretize em todas as instâncias e foros deste país a instalação adequada de centros de conciliação e de mediação.

\section{Procedimento do art. 334 e sessões sucessivas de mediação}

O Código trabalha como se tudo acontecesse num espaço mágico, tanto é assim que estabelece duas regras incompatíveis com a realidade:

1. A designação de audiência com antecedência mínima de 30 (trinta) dias. Ou seja, os centros de mediação terão que estar equipados e preparados para receber milhares (número que corresponde ao ajuizamento de ações nos principais foros do país) de feitos ajuizados, mês a mês. Se a pauta de audiências prévias conciliatórias e de contestação do procedimento sumário do art. 275 do CPC de 1973 em pouco tempo de aplicação - e em época menos traumática como a dos dias atuais - ruiu como um castelo de cartas, fazendo com o que o novo CPC desistisse desse procedimento, porque ressuscitálo, pelo menos em termos, em especial quanto às hipóteses de mediação? Se a audiência preliminar não funcionou para o procedimento sumário, por que deverá funcionar para as sessões de conciliação ou mediação? Pela tão somente previsão de órgãos auxiliares? Se for assim, volta-se ao problema anterior. 
2. A previsão de mais de uma sessão destinada à mediação - o que é da essência da atividade mediadora (arts. 14 e 18 da Lei n. 13.140/2015) - ficará adstrita ao período máximo de 2 (dois) meses, a contar da primeira sessão, conforme $₫ 2^{\circ}$ do art. 334 do CPC/2015. É fato que a Lei n. 13.140/15, em seu art. 28, dispõe igualmente que "o procedimento de mediação judicial deverá ser concluído em até sessenta dias, contados da primeira sessão, salvo quando as partes, de comum acordo, requererem sua prorrogação, vindo ao encontro do disposto no Código processual. Mas, por outro lado, a imposição de termo final não coaduna com a mediação stricto sensu, tanto é que a mediação extrajudicial, tratada nos arts. 21 a 23, não contempla regra similar e nem está presente a hipótese nas disposições comuns a ambas as espécies de mediação, conforme arts. 14 a 20, todos do estatuto antes referido.

Como a mediação visa a auxiliar e estimular as partes a identificar e desenvolver soluções consensuais para a controvérsia, esta previsão temporal mostra-se incompatível com a natureza da mediação, ficando muito claro que a lei processual, mesmo que pontualmente ratificada pela lei de regência da mediação, acaba falando língua diferente àquela ínsita ao instituto da mediação. De qualquer sorte, a aproximação entre os dois diplomas legais fica por conta da Lei da Mediação, resguardando um pouco essa eventual necessidade de maior dilação temporal, quando autoriza expressamente a prorrogação do prazo, o que lamentavelmente o texto processual esqueceu de contemplar.

Outra crítica ao procedimento normatizado está no comportamento exigido dos litigantes. A mediação pressupõe a autonomia de vontade das partes - de ambas as partes! - conforme art. $2^{\circ}$, inciso $\mathrm{V}$, da Lei $\mathrm{n}$. 13.140/15. Nos termos processuais, porém, o réu, em não tendo o autor desde logo manifestado na petição inicial que não tem interesse na mediação, está automaticamente compelido a comparecer à audiência preliminar, não lhe cabendo manifestar-se contrariamente, pois qualquer posição nesse sentido está absolutamente descartada frente ao disposto nos $₫ 4^{\circ}$, inciso I, e $\mathbb{8} 8^{\circ}$, ambos do art. 334. Não lhe resta opção. Esse tratamento desigual também atinge ao autor, pois como lhe cabe propor a ação, também lhe cabe, já na petição inicial, adiantar que não está disposto a submeter-se à mediação, o que não impede de o réu, valendo-se da prerrogativa legal, manifestar-se em sentido contrário, dizendo que tem interesse em mediar (ou conciliar, o problema é o mesmo). Isso porque nos termos do estatuto processual, não havendo consenso, a mediação se impõe, ou seja, o juiz ao receber a petição inicial, deve, assim mesmo, encaminhar as partes à audiência pois, uma vez citado o réu - e ele é citado para a audiência - terá ele oportunidade para dizer se concorda ou não com a mediação. De sorte que ou o juiz designa a audiência preliminar (ou encaminha para o centro competente, se for o caso) e determina a citação - ficando no limbo qualquer previsão de realização efetiva dessa audiência, ou primeiro cita o réu para dizer se quer ou não quer se valer da autocomposição. Chega-se à tal conclusão porque o texto legal só reverte o comando judicial de encaminhamento para audiência preliminar se ambas as partes se recusarem à autocomposição. 
Gustavo Osna denuncia, explorando situações hipotéticas e análogas, que a vontade de um dos litigantes acabará por se impor ao do outro ${ }^{23}$, o que acaba por desiquilibrar a igualdade das partes, isso sem descartar o evidente custo temporal que tal procedimento pode impingir ao processo, e o que é mais grave, sem qualquer previsão de êxito na composição.

\section{PROPOSIÇÃO: MEDIAÇÃO COMO FACULDADE DAS PARTES}

A partir de tais ponderações, conclui-se que a previsão da lei, bem assim as primeiras reflexões publicizadas quanto ao tema, em especial as divulgadas pela ENFAM, tendo como cogente a realização de uma audiência preliminar de mediação para os processos em geral mostra-se, a uma, em flagrante contradição ao instituto da mediação relativamente a uma de suas pedras basilares - a autonomia da vontade - e, a duas, nefasta para os objetivos que se propõe de construção de um processo democrático e consensual capaz de em tempo razoável obter a solução integral do conflito, visualizando-se mais razoável que a audiência de mediação não seja tida como comando cogente, mas como opção das partes em litígio.

A priorização, como norma fundamental, no estímulo às formas alternativas ou pelo menos distintas da tradicional composição da lide pelo processo adversarial e pela decisão judicial como decisão de império (força do Estado), permite concluir que o novo Código, assim como destacado por João Luiz Lessa Neto, adotou o modelo multiportas de processo civil, viabilizando que cada demanda deva ser submetida à técnica ou modelo afinado ao conflito com vistas a construção da solução ${ }^{24}$, buscando-se o que hoje passa a ser um ideal projetado para um processo civil democrático e efetivo, que é, dizendo com outras palavras, o processo adequado, com a composição do conflito adequada.

A ideia de multiportas está inserida no art. $3^{\circ}$ e seus parágrafos. No caput, partindo da cláusula de acesso à justiça, na medida em que reitera a garantia constitucional de que não se excluirá da apreciação jurisdicional ameaça ou lesão a direito, reproduzindo a via do processo litigioso, adversarial. No primeiro parágrafo reafirma a arbitragem como alternativa legítima, ainda que esse instituto não seja regulado pelo Código de Processo e sim por lei especial própria. A solução consensual vem nos $\$ \mathbb{S} 2^{\circ} \mathrm{e} 3^{\circ}$, oportunizando-se por esse caminho a conciliação, a mediação ou até outros métodos de solução consensual de conflitos. Tais disposições apontam para esse modelo de multiportas, todas, sem exceção, com um único desiderato: superar o conflito e alcançar a pacificação social.

Embora essa abertura para procedimentos distintos buscando a autocomposição ou a composição consensual mereça encômios, até porque significativamente democrática e participativa a construção da

\footnotetext{
${ }^{23}$ OSNA, Gustavo, ob. cit., p. 364.
} 
superação do conflito diretamente com e pelos respectivos sujeitos destinatários, o fato é que o requisito da adequação se impõe para o manejo da via mais compatível.

Aqui o ponto de divergência quanto à cogência da audiência de mediação imposta pelo art. 334 do CPC/2015, antes destacado.

Mais consentâneo com o instituto da mediação seria se essa escolha ficasse por conta das partes, propondo-se uma redefinição do art. 334, ex vi lege, nos seguintes termos ou similares:

Art. 334. Se a petição inicial preencher os requisitos essenciais e não for caso de improcedência liminar do pedido, o juiz designará audiência de conciliação, devendo ser citado o réu com pelo menos 20 (vinte) dias de antecedência, podendo as partes, de comum acordo, optar pela mediação, cumprindo ao autor na petição inicial e ao réu no prazo de 10 (dez) dias exercerem sua manifestação de vontade.

Por certo que a alteração do caput do art. 334 implicaria também uma redefinição dos respectivos parágrafos, mera consequência da nova redação, que aqui desimporta esmiuçar. Por outro lado, adequa-se a pauta à realidade fática da atividade cartorária, excluindo-se o prazo de 30 dias, que representa mero fetiche da lei, mas preservando o prazo de antecedência para o cumprimento da citação, até para oportunizar ao réu a prévia manifestação de concordância com a opção pela mediação. Por outro lado, o art. 319 do CPC/2015 também deveria receber redação mais específica, impondo-se ao autor, caso não recuse expressamente a autocomposição, declinar se acolhe a mediação ou se opta por submeter-se à conciliação.

Em apertada síntese, não havendo a dupla escolha pela mediação, impor-se-ia a cogência da forma de autocomposição remanescente, isso é, a conciliação - que tanto poder ser realizada pelo próprio juiz na absoluta impossibilidade prática de contar com núcleos de conciliadores, ou por centros devidamente instituídos para essa finalidade, na forma dos arts. 165 e seguintes do CPC/2015. Havendo, contudo dupla manifestação em favor da mediação, a audiência de conciliação perderia seu objeto, sendo as partes encaminhadas já originalmente, porque assim optaram, para a audiência de mediação, aqui, sim, indispensável a organização judiciária contar com mediadores devidamente preparados.

Tais modificações, nos termos em que aqui se propõe, dependem de alteração legislativa não só do art. 334, mas também do art. 319, que cuida da petição inicial. Como alternativa, beirando a um ativismo judicial, mas com amparo no poder construtivo da interpretação, considerando os princípios que regem a mediação e a ponderação entre os princípios da mediação e do processo civil, num diálogo entre as fontes, possível concluir, jurisprudencialmente e sem embargo da contribuição da doutrina, que a cogência da audiência preliminar se limita à hipótese da conciliação, essa sim afeita à atividade judicial, não abrangendo, porém, a mediação, que será facultativa, a critério dos próprios litigantes, hipótese em que o procedimento a ser adotado será o da Lei da

\footnotetext{
${ }^{24}$ LESSA NETO, João Luiz. O novo CPC adotou o modelo multiportas! E agora?, Revista Brasileira de Direito Processual RBDPRO, n. 92, Belo Horizonte, Editora Fórum, out/dez 2015, p. 99.
} 
Mediação, mais precisamente em seus arts. 14 a 20. Estabelecer-se a mediação como faculdade das partes é previsão que vem ao encontro da Lei n. 13.140/2015 e da própria essência do instituto, a ele se acomodando.

Estar-se-á, desta forma, dando-se um passo a mais em favor do processo como espaço democrático de composição de conflitos, evitando-se controvérsias incidentais ao processo e, por derradeiro, resguardando-se o próprio instituto da mediação e os princípios que a legitimam.

\section{CONSIDERAÇÕES FINAIS}

Premissa maior do novo CPC é a contemplação de um processo democrático, participativo e adequado ao conflito de direito material, representando faceta da democracia participativa e deliberativa. As opções de soluções consensuais ou de autocomposição foram expressamente contempladas no Código e elevadas à hierarquia de norma fundamental, adotando-se expressamente um sistema de justiça multiportas. Entre essas alternativas, merece, nos limites deste trabalho, o instituto de mediação, que não só foi expressamente contemplado no Código de Processo como também veio, depois de longa data de discussão no Congresso Nacional, regulamentado pela Lei n. 13.140, de 26 de junho de 2015 - portanto posterior ao CPC -, mas que entrou em vigo antes desse. Esse hiato entre um e outro estatuto provocou em alguns pontos divergências substanciais, em especial à que diz com o princípio da autonomia da vontade, fundamental à mediação, e a audiência preliminar de mediação ou conciliação do art. 334 do CPC/2015. A par de um indevido tratamento procedimental unívoco para a mediação e a conciliação, a realidade forense que convive com inúmeras insuficiências na organização do Poder Judiciário, tanto de pessoal como de infraestrutura, leva a concluir que os centros de mediação previstos no art. 165 do estatuto processual carecem de um largo tempo para a sua efetiva concretização. Um e outro fator são preponderantes para inviabilizar uma audiência preliminar de mediação, nos termos propostos pela lei processual, com bom êxito, podendo inclusive produzir resultado nefasto e contrário, impondo uma dilação temporal não pretendida na composição do conflito, e até vedada pela garantia constitucional da tempestividade do processo.

Resgatar-se - o que está positivado na lei da mediação e que é profusamente defendido pela doutrina específica - o princípio da autonomia de vontade e a garantia de que ninguém será mantido em procedimento de mediação, convertendo a cogência da audiência do art. 334, relativamente à mediação e tão somente à mediação, em mera faculdade das partes, oportunizando-lhes manifestação nesse sentido, é o caminho salutar que se sugere.

Eventual silêncio das partes nesse sentido, manteriam viva e adequada a via da conciliação, inclusive em audiência preliminar, até porque se trata de instituto mais afinado à atividade judicial.

Por certo que tais modificações, em termos ideais, carecem de alteração legislativa, mas nada impede que a profusa construção pretoriana e o trabalho doutrinário, podem, sim, contribuir para que se adequem as regras de 
cogência do art. 334, limitando-as à audiência de conciliação e liberando a mediação à faculdade das partes.

\title{
CONSENSUAL SOLUTION AND THE AUDIENCE OF THE ART. 334 OF NEW CPC VERSUS MEDIATION AS A FACULTY OF PEOPLE UNDER JURISDICTION
}

\begin{abstract}
The present study starts from the affirmation of the process as democratic space and it focus on the conciliation and the mediation institutes included in the preliminary hearing of the article 334 of the new $\mathrm{CPC}$ and its fuzzy and generic cogency. As critical analysis this works aims to compare the law 13.140/15 and the new CPC, especially in relation to the autonomy of will and the rule that no one will be forced to remain in mediation, accusing a diametrical divergence between the two laws. This study tries to work with the natural difficult of judicial organization to carry out the purpose of stimulating consensual composition, assuming, therefore, through a deductive methodology, a larger and more generic premise for a smaller and more specific, through bibliographical research, the effect of achieving a better understanding of mediation and its application to legal proceedings, by the adoption of mediation as a faculty of the people under jurisdicion in order to allow the implementation of a civil procedure effectively broad democratic access and effectiveness of its purposes.
\end{abstract}

Keywords: Consensual solution. Cogency of the preliminary hearing. Judicial conciliation. Mediation as a faculty of the people under jurisdiction.

\section{REFERÊNCIAS BIBLIOGRÁFICAS}

ABELHA, Marcelo. Manual de direito processual civil, 6a ed., Rio de Janeiro: Forense, 2016.

AZEVEDO, André Gomma (coord.). Estudos em Arbitragem, Mediação e Negociação, Vol. 3, Brasília: Grupos de Pesquisa, 2004.

BERNAL, Francisco Chamorro. La tutela judicial efectiva; derechos y garantias procesales derivados del artículo 24.1 de la Constitución. Barcelona: Bosch, Casa Editorial, S.A, 1994.

DIDIER JR., Fredie. Curso de Direito Processual Civil, V. 1, Salvador: Editora JusPodivm, 2015.

FERNANDES, Luís Eduardo Simardi, in DELLORE, Luiz et al. Teoria Gera do processo contemporâneo, São Paulo: Atlas, 2016.

JOBIM, Marco Félix. Teoria, História e Processo: com referências ao CPC/2015, Porto Alegre: Livraria do Advogado Editora, 2016, p. 79-81.

LEAL, Rogério Gesta. Estado, administração pública e sociedade: novos paradigmas. Porto Alegre, Livraria do Advogado Ed., 2006. 
LESSA NETO, João Luiz. O novo CPC adotou o modelo multiportas! E agora?, Revista Brasileira de Direito Processual RBDPRO, n. 92, Belo Horizonte, Editora Fórum, out/dez 2015, p. 97-109.

MARINONI, Luiz Guilherme; MITIDIERO, Daniel. Comentários ao Código de Processo Civil, artigos $1^{\circ}$ ao 69. (Coleção Comentários ao Código de Processo Civil, V.1, coordenação Luiz Guilherme Marinoni, Sérgio Cruz Arenhart, Daniel Mitidiero), São Paulo: Editora Revista dos Tribunais, 2016.

MIRANDA, Jorge. Formas e sistemas de governo. Rio de Janeiro: Forense, 2007.

OSNA, Gustavo. A "audiência de conciliação ou mediação" no novo CPC: seis (breves) questões para debate, in Revista de Processo, vol. 256, junho, 2016, p. 349-370.

PINHO, Humberto Dalla Bernardina de; VIDAL, Ludmilla Camacho Duarte. Primeiras reflexões sobre os impactos do novo CPC e da Lei de Mediação no Compromisso de Ajustamento de Conduta. In: Revista de Processo, vol. 256, junho, 2016, p. 371-409.

QUINTAS, Fábio Lima. Para que um novo Código de Processo Civil? Uma reflexão sobre os novos contornos da função jurisdicional. In: Revista de Processo, vol. 256, junho, 2016, p. 295-315.

RIBEIRO, Cristiana Zugno Pinto; FISCHER, Roger. A audiência de conciliação ou de mediação do novo CPC. In: Procedimento comum: da petição inicial à sentença à luz do novo Código de Processo Civil, TESHEINER, José Maria; MACEDO, Elaine Harzheim; THAMAY, Rennan Faria Krüger (Coord.), Curitiba: Juruá, 2015.

THEODORO JÚNIOR, Humberto. Curso de Direito Processual Civil: teoria geral do direito processual civil, processo de conhecimento e procedimento comum, 57a ed., Vol. I, Rio de Janeiro: Forense, 2016.

Trabalho enviado em 28 de setembro de 2016.

Aceito em 09 de fevereiro de 2017. 